ich fragen darf; ПВ контактив-попередження Lass dir das heute eine Warnung sein.

Таким чином, контактовстановлююча, контактопідтримуюча та контакторозмикаюча складові є обовязковим елементом вдалої цілеспрямованої двосторонньої інтеракції. За нашими даними, метакомунікативні ПВ здебільшого реалізують підтримання контакту, у окремих випадках вони виконують контактовстановлюючу або контакторозмикаючу функцію.

\title{
Література:
}

1. Матюхина Ю. В. Розвиток системи фатичної метакомунікації в англійському дискурсі XVI - XX ст. : автореф. дис. на здобуття наук. ступеня канд. філол. наук : спец. 10.02 .04 «Германські мови». Харків : Константа, 2004. 20 с.

2. Почепцов Г. Г. Фатическая коммуникация // Семантика и прагматика синтаксических единств. Калинин : Калининск. гос. ун-т, 1981. С. 52-59

3. Laver J. Communicative functions of phatic communion // Organization of behaviour in face to face interaction / Ed. by Adam Kendon, Richard M. Harris, Mary Ritchie Key. Paris : The Hague, 1975. P. 215-238.

DOI https://doi.org/10.30525/978-9934-26-110-7-46

\section{ХАРАКТЕРИЗАЦІЯ САТИРИ ЯК ЗАСОБУ ВИРАЖЕННЯ КОМІЧНОГО У БРИТАНСЬКОМУ МЕДІАДИСКУРСІ (НА МАТЕРІАЛІ ЖУРНАЛУ РRIVАТЕ ЕYЕ)}

\author{
Юрчишин В. М. \\ асистент кафедри англійської філологї \\ Прикарпатський національний університет імені Василя Стефаника \\ м. Івано-Франківськ, Украӥна
}

Сатира $є$ широковживаним засобом вираження критичного ставлення до невідповідності між існуючим та бажаним станом речей у супроводі комічного ефекту [3, с. 233]. Завдяки розмаїттю жанрових форм та прийомів, використовуваних сатириком, у науковому дискурсі виділяють літературознавчий та лінгвістичний підхід до вивчення сатири. Літературознавчий підхід, який стоїть у витоках наукового інтересу до сатири, розглядає сатиру як засіб вираження комічного, де комічне $\epsilon$ 
унівесальною категорією, яка має соціальну природу і яка існує поза простором і часом[1, с. 23-28]. Актуальність дослідження сатири у медіадискурсі, який висвітлює всі найбільш значущі позитичні та негативні зміни у суспільстві, зумовлена тим що медіадискурс першим реагує на негативні суспільні трансформації, які виступають об’єктом сатиричної критики.

Метою дослідження $є$ характеризація сатири як засобу вираження комічного у британському медіадискурсі (на матеріалі сатиричного журналу Private Еуе). Матеріалом дослідження є тексти 75 статей журналу Private Eуе за 2019-2021 pp.

Методологією дослідження $\epsilon$ класифікація прийомів створення комічного ефекту запропонована Б. Дземидоком, в якій автор виділив такі прийоми створення комічного ефекту: а) видозміна $i$ деформація явищ, б) несподівані ефекти та неочікувані співставлення, в) неспівмірність у відноченнях та зв'язках між явищами, г) поєднання цүілком різнорідних явищ, д) підкреслення явищ, які за суттю або за видимістю відхиляються від логічної чи аксіологічної норми $[2$, c. 66-88].

У британському сатиричному дискурсі автор апелює до прийому створення комізму шляхом_видозміни та деформації за допомогою широкого спектру лексичних, стилістичних та прагматичних прийомів, які здатні гіпертофувати сприйняття об'єктів сатиричної критики.

Наприклад, у статті Isn't Boris Marvellous?

When he came into the room it was like the Heavens had opened and the pentecostal flame had set fire to everyone in the assembled multitude. And when he spoke, a clap of thunder boomed through Room No.94 in the Chuter-Ede corridor at Carlton house. ...we have been waiting for, the Messiah, who shall be called wonderful by me in my colomn and shell redeem his people... [Private Eye 15 November - 28 November 2019, c, 28] сатирик апелює до гіпербол, підсилених прецедентним феноменом the Messiah, які допомагає сатирику гіпертрофувати надприродні здібності британського прем'єр-міністра.

Сатирик створює неспівмірність у відношеннях та зв'язках між явищами за допомогою антитез («The government gave its clearest indication yet yesterday that it would fully back and totally oppose the introduction of vaccine passports(Private eye 16 April - 29 April 2021, 30)

Засобом реалізації прийому поєднання різнорідних речей часто виступає такий тип метафори, як персоніфікація людини за допомогою неживих предметів. Наприклад, у наступній сатиричні статті автор персоніфікує американську бізнес леді Дженіфер Аркурі (Jenifer Arcuri), 
яка начебто мала близькі відносини із прим'єр-міністром Великобританії Б. Джонсоном в образі дивана.

\section{The Sofa Speaks}

(I was an innocent sofa from a distant land (IKEA) when I came into Boris's life. AS soon as he ripped the plastic off me, I knew immediately that Boris was interested. I wasn't surprised...I was flattered, of course, but as he flopped down on top of me, I knew I was being used. He used to playfully slip his hands down the back of my cushions, but then I realized he was only looking for small change to buy beer for some blond IT specialist...)[Private Eye 2 April - 15 April 2021, 29]. Використання такого типу персоніфікації применшує значимість Дж. Аркурі як людини, та підкреслює зневажливе ставлення премєр-міністра до осіб протилежної статі.

Прийом підкреслення явищ, які за суттю або за видимістю відхиляються від логічної чи аксіологічної норми реалізується за допомогою ехо-висловлень, які протиставляються контекстуальній інформації, зокрема знанням про навколишній світ. Розглянемо, наприклад, статтю написану незадовго після гучного інтервю принца Гаррі та Меган Маркл із О. Вінфрі.

How will you score in this palace puzzler?

All you have to do is to spot the logical fallacy in Harry and Meghan's reasoning, as featured in their historic ratings-busting Oprah interview:

1. I don't read the tabloids, but they are so unpleasant I had to leave the country.

2. The racism in Britain was so bad we've come to the United States.

3. For security reasons, it's better to live in a country where everyone has a gun....

8. Meghan is not to blame for me leaving the royal family, I couldn't have done it without her.

10. I' $m$ broke, apart from the millions my mother left me [Private Eye 19 March - 1 April 2021, c.30].

У цьому прикладі сатирик підкреслює комічність ситуації за допомогою ехо-висловлень основних ідей Гаррі та Меган, які самі по собі $є$ абсолютно алогічними. Окрім того, алогічність проявляється, коли в дію вступає контекстуальна інформація, зокрема фонові знання про те, що проблема расизму є більш гостровираженою у США ніж у Британії чи те, що не можливо знати зміст тих журналів, які людина не читає зовсім.

Загалом, у більшості випадків сатирик апелює до декількох прийомів створення комізму одночасно в межах однієї статті, однак у досліджуваних статтях простежується домінування прийому видозмін та 
деформацій явищ, реалізованих за допомогою перебільшення певних ознак чи дій об'єктів сатиричної критики та прийому неочікуваних співставлень та підкреслень якищ, які відхиляються від логічних норм.

Отже, сатира як засіб вираження комічного характеризується апеляцією до таки прийомів комізму: а) видозміна і деформація явищ, реалізована за допомогою перебільшення, карикатур, пародіювання та применшення; б) несподівані ефекти та неочікувані співставлення, реалізовані за допомогою антитез; в) невідповідність у відношеннях та зв'язках між явищами передана за допомогою анахронізму із сфери мислення; г) поєднання абсолютно різнорідних явищ реалізоване за допомогою персоніфікації та гротеску; д) підкреслення явищ, які за суттю або за видимістю відхиляються від логічної чи аксіологічної норми. Домінуючими прийомами є деформовані видозміни та прийом неочікуваних співставлень.

\section{Література:}

1. Борев Ю. О комическом. Москва, 1957. $241 \mathrm{c.}$

2. Дземидок Б. О комическом [перевод с польского]. Москва, 1974. - 224 c.

3. Юрчишин В. М. Засоби реалізації структурних елементів сатири за методологією П. Сімпсона (на матеріалі британського медіадискурсу) Вчені записки ТНУ імені В. I. Вернадського. Серія: Філологія. Журналістика, Київ, 2021. С. 233 - 239. DOI: 10.32838/2710-4656/2021.1$2 / 41$ 